\title{
Silencing linguistic diversity: the extent, the determinants and consequences of the monolingual beliefs of Flemish teachers
}

\section{Reinhilde Pulinx, Piet Van Avermaet \& Orhan Agirdag}

To cite this article: Reinhilde Pulinx, Piet Van Avermaet \& Orhan Agirdag (2017) Silencing linguistic diversity: the extent, the determinants and consequences of the monolingual beliefs of Flemish teachers, International Journal of Bilingual Education and Bilingualism, 20:5, 542-556, DOI: 10.1080/13670050.2015.1102860

To link to this article: $\mathrm{http}: / / \mathrm{dx}$. doi.org/10.1080/13670050.2015.1102860

\section{Published online: 27 Oct 2015.}

\section{Submit your article to this journal $\square$}

Џll Article views: 345

Q View related articles $ᄃ$

View Crossmark data ¿`

Citing articles: 4 View citing articles 5 


\title{
Silencing linguistic diversity: the extent, the determinants and consequences of the monolingual beliefs of Flemish teachers
}

\author{
Reinhilde Pulinx ${ }^{a}$, Piet Van Avermaet ${ }^{a}$ and Orhan Agirdag ${ }^{b, c}$ \\ aLinguistics Department, Centre for Diversity and Learning, Ghent University, Gent, Belgium; ${ }^{b}$ Laboratory for \\ Education and Society, University of Leuven, Leuven, Belgium; 'Department of Educational Sciences, University of \\ Amsterdam, Amsterdam, The Netherlands
}

\begin{abstract}
This article aims to deepen our understanding of the dynamic interaction between language policies, school characteristics and teachers' beliefs about monolingualism. The study takes place in Flanders (Belgium), a region characterized by educational policies which are based on a stringent monolingual ideology. Based on a survey of 775 teachers from across 48 secondary schools, we examined how these policies affected teachers' beliefs, whether and how teacher beliefs vary between schools, and what the consequences of these beliefs are. The results of our multilevel analysis indicate that teachers strongly adhere to monolingual policies, while there are also significant differences across schools, which are related to the ethnic composition of those schools. Furthermore, a stronger adherence to monolingualism was found to trigger teachers to have lower expectations about their students but not about their ability to teach. Finally, implications for policymakers are discussed.
\end{abstract}

\section{ARTICLE HISTORY}

Received 3 November 2014

Accepted 9 September 2015

\section{KEYWORDS}

Monolingualism; teachers' beliefs; teachers' expectations; language ideology; Flanders

\section{Introduction}

Over the past two decades, education policies in many Western countries have emphasized language use and proficiency in the dominant language as a condition for academic success. The use of and proficiency in the home languages of pupils with different social and ethnic backgrounds are valued by policymakers as elements of identity building and cultural integrity, but not as didactic capital for academic performance or related to the acquisition of the dominant language (Extra, Spotti, and Van Avermaet 2009; Van Avermaet 2009;Cummins 2011, 2013; Agirdag 2014). In most countries, home languages are now placed explicitly outside the curriculum and attributed no value in academic terms. While in the late 1980s and 1990s, some educational policies did provide for curricula which were bilingual, or which used students' home languages and culture such as Intercultural Education programs and Education in Home Language and Culture programs, ${ }^{1}$ these initiatives have been gradually dismantled and replaced by policy measures such as L2 submersion programs, remedial language courses and testing policies and practices focusing on the dominant language (Extra and Yagmur 2004; Blommaert and Van Avermaet 2008; Vaish 2012). The current education policies in different Western countries are based on monolingual ideologies and put into practice by school principals, teachers and school staff through mission statements, curricula and language tests (Shohamy 2006; Gkaintartzi, Kiliari, and Tsokalidou 2015).

Thus, in order to be effective, the language policies developed at macro-level need to be internalized by social actors at micro-level and education systems play an important role in this process (Bourdieu 1991). However, an education system cannot be regarded as a static entity. Most 
schools have a certain level of autonomy (particularly in Flanders, where this study is conducted, seeing as the Belgian constitution guarantees in article 24 a high level of freedom of education ${ }^{2}$, and we are therefore likely to find differences at school level (i.e. meso-level) in how teachers reproduce the macro-level language policies. Until now, this macro-meso-micro link has received little attention in educational and sociolinguistic research. Hence, the first objective of this study is to examine how the language policies are reflected in teachers' beliefs in different schools. More specifically, we will examine the degree to which teachers adhere to monolingual beliefs in education and whether these beliefs vary across schools.

Secondly, most empirical studies on teachers' beliefs on multilingual education make use of a qualitative approach (for recent studies, see Valdiviezo 2009; Ramaut et al. 2013; Pulinx, Agirdag, and Van Avermaet 2014). These qualitative studies have greatly contributed to our understanding of the present topic and have been crucial for identifying teachers' beliefs in linguistically diverse classrooms. However, an exclusively qualitative approach has significant limitations. The small sample sizes and the lack of a comparative perspective in many of these studies do not allow us to draw conclusions about the conditions that can intensify or diminish teachers' beliefs about monolingual policies. Most importantly, a quantitative (multilevel) approach might inform us on how teachers' beliefs are influenced by the characteristics of the school context in which they function (see also Agirdag, Van Avermaet, and Van Houtte 2013). Therefore, the second objective of this study is to examine to what degree school characteristics determine the level of teachers' adherence to or rejection of monolingual education ideologies by using a larger sample of schools and teachers.

Third, previous studies have tended to stress the fact that teachers' monolingual beliefs negatively affect the academic achievement of linguistically diverse students (see Crowl and MacGinitie 1974; Godley et al. 2006; Wheeler 2008). However, it is not clear how and why teachers' beliefs about monolingualism relate to achievement performance. The third objective of the present study is therefore to examine the relationship between teacher's beliefs about monolingualism and teacher's expectations of their students and themselves. More specifically, we expect that a stronger adherence to monolingual beliefs will trigger teachers to have lower expectations of both students' ability and engagement (i.e. teacher trust), and also of their own professional ability (i.e. teacher efficacy).

This paper has five parts. The first part outlines the conceptual framework used to analyze the data collected in relation to the formulated research objectives. Secondly, we present the socio-political context of Flanders where the study is situated. Thirdly, we outline the research methodology and data analysis techniques. Next, the findings are discussed and summarized. And finally, the paper concludes with a discussion of the implications of the research findings.

\section{Conceptual framework}

The conceptual framework we used to examine the relation between language policies in education and teachers' beliefs on language use in education consists of three elements: (1) language policies as an expression of language ideologies; (2) the relation between school characteristics and teachers' beliefs and (3) the relation between monolingual beliefs and teachers' expectations. For each of these elements of the conceptual framework, we have formulated a research question.

\section{Languages ideologies}

Language ideologies can be defined as systems of beliefs and ideas about the role which language holds within the cultural, social and political context of a specific society (Woolard 1998; Spolsky 2004). The construction of these language ideologies does not happen abruptly or accidentally but rather it is always situated in specific social, historic and political contexts (Blommaert and Verschueren 1998; Blackledge and Pavlenko 2001). Furthermore, language ideologies are not only linked to their social and political contexts, they are also related to instances of identity construction, 
power relations and assertion of power in societies (Kroskrity 2000; Pavlenko 2002). As Woolard (1998) stated: 'Ideologies of language are rarely about language alone.'

Language ideologies often result from cognitive/academic dissonance and qualify as common sense thinking, are then put into practice by those in authority through language policies, more specifically through language education policies. Language policies are instruments used to achieve certain political goals and to legitimize ideological choices. Shohamy (2006) sees language education policies as powerful mechanisms for creating de facto language practices in educational institutions, given the fact that children and young people are obliged to attend school until a certain age. This explains why languages policies are implemented and maintained, even though theoretical and empirical evidence to substantiate these policies are lacking.

Language education policies are mostly developed and dictated at regional and national level. They are implemented through official documents such as curricula or mission statements and carried out by school principals, teachers and other school staff (Shohamy 2006). Teachers, as individual professionals and members of a school team, implement these language policies in interaction with the local school context, their own experiences and beliefs (Creese 2010).

The educational system has the power to classify different languages (and different cultural contents) as more or less valuable and as legitimate or illegitimate. This power is due to the system's monopoly in the production of legitimate language competence. The education system will therefore strive for its own reproduction, in order to hold on to the social value of the linguistic competence it produces and its capacity to function as linguistic capital (Bourdieu 1979). Bourdieu also outlined the unique position of education with regard to social language use and legitimate language competences. He sees the education system as a large-scale production process delivering producers and consumers of language. Bourdieu argued that the domination of one language over one or more other languages and varieties can only persist if both the dominant and dominated groups alike accept the superiority of one proclaimed dominant language. Language ideologies contribute to the perpetuation of this 'institutional circle of collective misrecognition' (Bourdieu 1991; see also Blackledge and Pavlenko 2001).

However, this process should not be regarded as merely mechanical. There might be individual differences between teachers who as individuals have a level of agency allowing them to negotiate or reject structural processes. Moreover, as most schools have a certain level of school autonomy (particularly in Flanders where this study was conducted, see below), there might be differences between schools. Hence, the first research question is as follows: to what extent do individual teachers adhere to the monolingual language policies as currently implemented in the Flemish education system and is there significant variation between schools?

We hypothesize that teachers will reproduce monolingual language policies, while important differences can be expected between schools given the school autonomy in Flanders.

\section{The relation between school characteristics and teachers' monolingual beliefs}

As indicated in the above paragraph, language policies are to some extent expressions of language ideologies and, consequently, expressions of the beliefs of regional and national policymakers. Teachers' beliefs are, amongst other things, formed by these prescribed policies and policy measures. Teachers' beliefs are not only shaped directly by national policies and policy frameworks but are also to a large extent influenced via the organizational, pedagogical and didactical school characteristics (Oakes 1985; Lee 2000; Van Houtte 2011). Based on the existing literature, we selected two school features as relevant for the understanding of the extent and effect of teachers' monolingual beliefs, namely school ethnic composition and school curriculum track.

Until now, research regarding school composition has mostly explored the effects of these school characteristics on pupils (e.g. Dumay and Dupriez 2008; Agirdag, Van Houtte, and Van Avermaet 2012); however, it is reasonable to assume that the composition of schools has an equal impact on teachers' beliefs. Existing stereotypes associated with the characteristics of a school population - based 
on socio-economic composition of the pupils, ethnic composition of student body, curriculum track influence society's beliefs regarding the language proficiency (in the majority language) and academic achievement of the pupils alongside the wider educational quality of the schools (Agirdag and Van Houtte 2011; Van Houtte 2011).

The first characteristic influencing teachers' beliefs is the curriculum track provided by schools. The Flemish education system predominantly consists of three tracks: the general track (ASO), technical track (TSO) and vocational track (BSO). These three tracks fit into a clear hierarchy of social appreciation (Duquet et al. 2006; Jacobs 2009), with the general track at the top and the vocational track at the bottom of the social ladder, and technical education holding the middle position. Teachers are mostly assigned to one of these tracks and most schools only cover certain tracks. Hence, students are highly separated in different schools according to their curriculum track. Linguistic minority students are highly concentrated in the less well-regarded tracks (Duquet et al. 2006; Hirtt, Nicaise, and de Zutter 2007; Jacobs 2009). Previous studies in Flanders and elsewhere have indicated that teachers' beliefs are significantly linked to the curriculum tracks: teaching in academic and advanced tracks is associated with higher expectations than teaching in vocational tracks (Oakes 1985; Ennis 1994; Lee 2000; Van Maele and Van Houtte 2011).

Secondly, the composition of the school may play a decisive role here, since teachers' evaluations are liable to be influenced by existing social stereotypes regarding certain characteristics of the composition of the student body (Van Houtte 2011). There is a general stereotypical belief that schools with a high percentage of ethnic minority and low socio-economic status (SES) students are 'bad' schools (Merry 2012). Previous studies have shown that teachers working in schools of this type have lower expectations about the ability of their students (Rumberger and Palardy 2005) and tend to problematize the existing linguistic diversity (Agirdag, Van Avermaet, and Van Houtte 2013).

Following on from the above, the second research question of this study is as follows: what is the relation in the Flemish context between the ethnic composition and curriculum track of a school and its teachers' beliefs about monolingualism. We expect a higher adherence to monolingualism in the case of teachers working in schools with a higher share of ethnic minority students and teachers working in the vocational track.

\section{Relation between teachers' monolingual beliefs and teacher-pupil interaction}

Above, we discussed the possible effects of top down education policies and policy measures (macrolevel) and school characteristics (meso-level) on teachers' beliefs (micro-level). However, these beliefs might in turn have an (indirect) impact on student achievement. The most well-known example of such a teacher effect is outlined in the study known as 'the Pygmalion Effect' (Rosenthal and Jacobson 1968). This study demonstrated the effect of teachers' beliefs on their expectations about the academic performance of their students. Teachers' expectations, subsequently, were shown to have an effect on the actual academic achievement of their pupils (Rosenthal and Jacobson 1968). Low expectations from teachers have a negative effect on pupils' achievement. Similarly, it is likely that teachers' beliefs about the use of (home) languages in education will have an effect on other beliefs these teachers hold; as well as on the beliefs held by pupils; and teacher-pupil interaction (see Godley et al. 2006; Wheeler 2008).

Wheeler (2008) indicated that most teachers lack the necessary pedagogical and didactical training to use the plurilingual competencies of pupils as an added value in the learning process. Consequently, speaking dialects or code switching is mostly misdiagnosed as poor language proficiency in the majority language (Garcia and Wei 2013). On the other hand, teachers who are exposed to basic sociolinguistic principles are more likely to reject the most extreme stereotypes associated with different language varieties (Bowie and Bond 1994). Previous studies also showed that negative attitudes to stigmatized languages are related to lower teacher expectations regarding pupils' use of these languages (Godley et al. 2006; Agirdag, Van Avermaet, and Van Houtte 2013). For instance, through observation an indirect relation was found between language use and teachers' 
expectations. Teachers were found to give lower grades to oral work presented in a vernacular dialect, even when the work presented was of the same quality as work presented in the standard language variety (Crowl and MacGinitie 1974; Ramaut et al. 2013).

The literature discussed above indicates that negative teacher beliefs about stigmatized languages (and the consequent adherence to monolingual policies in education, as related to exclusive use of the majority language in educational settings) might lead teachers to expect students to have a reduced ability to reach prescribed academic objectives. When strong monolingual beliefs lead to lower expectations, teachers will suspect that their teaching ability has diminished, that is, that they have lower self-efficacy (Tschannen-Moran and Hoy 2001). Likewise, we can expect a negative relation between strong monolingual beliefs and the level of trust teachers have in their pupils' academic engagement. By this, we mean the level of confidence teachers have in their pupils to meet individual obligations and expectations regarding school work and effort. However, we are not aware of any previous empirical study that examined the relationship between monolingual beliefs on the one hand and teacher self-efficacy or teacher trust on the other hand.

Building on the literature discussed above, a third research question can thus be formulated: can we find a relation between monolingual teachers' beliefs and the level of teachers' self-efficacy trust in their pupils? Based on the literature as discussed above, we expect to find a negative relation, namely that a strong adherence to monolingual education policies relates to a lower sense of selfefficacy and to lower trust in pupils.

\section{Socio-political context and education policies in Flanders}

In terms of context, in the 1980s and 1990s, the Flemish education system showed more openness towards plurilingualism and home languages (other than the majority language) in school. However, since then, programs including bilingual curricula or curricula in home language and culture have gradually been dismantled and replaced by policy measures such as L2 submersion programs, remedial language courses and language testing in the dominant language (Extra and Yagmur 2004; Blommaert and Van Avermaet 2008; Agirdag 2010). This policy shift in education policies can for the most part be explained by two processes taking place in Flanders. Firstly, over recent decades a process of sub-state nation building has been taking place in Flanders; secondly, there has been a great increase in the impact of international comparative research programs (such as PISA, TIMSS and PIRLS ${ }^{3}$ ) on education policies.

Since the start of the twentieth century, the region of Flanders has continuously worked towards increased cultural, political and financial autonomy. These processes of sub-state nation building and nationalism in Flanders cannot be isolated from the rapid transition of Flanders into a multicultural society since World War II. The transition into a super diverse society (Vertovec 2007) reinforces the quest for a recognizable Flemish identity, comprising a common language, shared norms and values.

In this context of sub-state nation building and increasing diversity, concepts such as 'home language' (thuistaal), 'minority language' (minderheidstaal) and 'foreign language speaker' (anderstalige) have acquired a particular meaning. These terms almost exclusively refer to (second or third generation) different groups of migrants - in particular migrant workers originating from Morocco or Turkey - and more recently people migrating via family reunification, matrimonial migration and refugees (De Rycke and Swyngedouw 1999; Nouwen and Vandenbroucke 2011). Widespread social prejudices ascribe to these groups of pupils low levels of proficiency in the Dutch language, the use of 'low status' home languages such as Turkish or Arabic and low levels of academic achievement (Mahieu and Clycq 2007; Blommaert and Van Avermaet 2008; Nouwen and Vandenbroucke 2011).

Secondly, the policy shift towards monolingualism is related to the increasing influence of international comparative research programs, in particular the PISA study. Although the mean level of achievement is very high in Flanders, detailed analyses of the PISA results unveiled the persistence of social inequality within the Flemish education system (De Meyer, Pauly, and Van de Poele 2005; De Meyer 2008; Jacobs 2009). None of the other participating countries/regions reported a greater 
gap in performance between (1) pupils with high SES and pupils with low SES; (2) pupils with a nonimmigrant background and immigrant pupils and (3) native L1 speaking pupils and pupils who speak (mostly) another language at home (Jacobs 2009).

Flemish policymakers made use of the PISA results to implement more stringent language policies. An explicit monolingual policy framework was formulated, based on three main assumptions: (1) Dutch language proficiency is a condition for participation in education; (2) the use of a home language other than Dutch is detrimental to academic success and leads to insufficient Dutch language proficiency and (3) insufficient Dutch language proficiency at the start of an education trajectory is a deficit that needs to be alleviated in order to achieve academic success. These three assumptions are formulated based on an analysis of the main policy documents on language in education, issued by Flemish policymakers in the past decade (Pulinx and Van Avermaet 2014).

For the first time, a specific policy document on language policy in education was published by the Flemish Minister of Education (Vandenbroucke 2006): 'Setting the bar high for languages in every school. Good for the strong, strong for the weak'. Since then, proficiency in Standard Dutch has been more explicitly proposed as the most important condition for academic success. The Minister of Education described his three policy priorities as follows: 'Language, language and language' (Vandenbroucke 2007), hereby declaring that multilingualism leads imperatively to 'zerolingualism' when implemented headlong (Flemish Parliament 2007). In 2011, the subsequent Flemish Minister of Education (2009-2014) published a second language policy document, entitled: 'Moving linguistic boundaries together' (Smet 2011), mainly continuing the policy guidelines set out by his predecessor.

As such, this is the socio-political context in which we will examine to what degree monolingual beliefs are internalized and expressed by secondary school teachers Flanders.

\section{Methods}

\section{Population and sample}

Data were collected during the 2010-2011 school year as part of a large-scale, mixed-method and multidisciplinary research project - BET YOU! - on the school careers of pupils with an immigrant background in secondary education (SE) in three cities in Flanders (Antwerp, Ghent and Genk; Clycq et al. 2014). To obtain a representative sample of schools and teachers in these three cities, all 118 schools which offer general, technical of vocational SE curriculum were invited to participate in the research project. Secondary schools providing special needs programs were not included in the survey. In total, 48 schools (40.7\%) of the schools in the population agreed to participate. The participation of teachers was dependent on school participation. Within the 48 school that agreed to participate, 774 teachers (31\%) responded to our survey by filling out an anonymous online questionnaire. For this purpose, we made use of the online survey service 'SurveyMonkey'.

\section{Research design}

The quantitative data consisted of a clustered sample of teachers from within the schools. Because the data were at different levels (individual teacher level and school level), multilevel modeling was most appropriate (SPSS Version 20, MIXED procedure is used). Missing data were handled with the multiple imputation procedure: five imputations are requested and the pooled results were shown. With respect to the first research objective, we started by examining teachers' responses to each item on the monolingualism scale (see Variables section) in order to determine the extent to which teachers adhered to or rejected monolingualism in education. Then, we calculated the degree to which the variance in teachers' beliefs about monolingualism was present at the school level by calculating a multilevel unconditional model for the monolingualism scale. This informed us as to whether teachers' beliefs about monolingualism significantly vary between schools. 
With respect to the second research objective (i.e. determinants of monolingualism), we conducted a multilevel regression analysis with monolingualism beliefs as the outcome and school ethnic composition and track (curriculum) as exploratory variables. Additionally, we included teacher gender, teacher experience and school sector as control variables.

Regarding the third research objective (i.e. consequences of monolingualism), two multilevel regression models were calculated: one with teachers' trust in students as outcome and a second with teachers' self-efficacy beliefs as the outcome. In these two models, teachers' monolingualism beliefs were entered as the main exploratory variable, while we included teacher gender, teacher experience, school track, and school ethnic composition and school sector as control variables.

\section{Variables}

\section{Monolingualism}

Teachers' beliefs regarding the use of (home)languages in education (monolingual beliefs) were measured using eight items (see Table 2). These items have been used in a previous research project conducted in Flanders (i.e. the SIPEF project, see Agirdag, Van Avermaet, and Van Houtte 2013). The items as used in the present research project were only adapted to the context of secondary education, whereas the items used in the SIPEF project were used in the context of primary education. Answer categories and their scores were as follows: (1) absolutely disagree, (2) disagree, (3) neutral, (4) agree and (5) completely agree. Items 3, 4 and 6 were reverse coded (see Table 2). Responses to these eight items were averaged. Mean score $(M)$ was 3.740, with a standard deviation (SD) of 0.624 . The scale yielded a satisfactory Cronbach's alpha of 0.816 (see Table 1 for descriptive statistics). A multilevel confirmatory factor analysis revealed a satisfactory fit for a one-factor model, that is, the value of root mean square error of approximation was 0.091 and the standardized root mean square residual (SRMR) was 0.073 . A SRMR value less than 0.08 is generally considered a good fit (Hu and Bentler 1999).

\section{Trust}

Teachers' trust in students was measured with 10 items derived from the trust scale developed by Hoy and Tschannen-Moran (1999). Example items are: 'I have to closely supervise the pupils' or 'The pupils cheat if they have the chance'. Teachers had five possible categories of response, ranging from absolutely disagree (scored 1 ) to completely agree (scored 5 ). Responses to these 10 items were averaged $(M=3.191 ; S D=0.499$; see Table 1$)$. Cronbach's alpha for this scale was 0.827 .

\section{Self-efficacy}

Teacher's self-efficacy was measured using 12 items from the Teachers' Sense of Efficacy Scale (Tschannen-Moran and Hoy 2001). Teachers were asked to indicate the extent to which they perceive themselves as capable of conducting a particular action successfully and they had five possible response categories, ranging from absolutely disagree (scored 1) to completely agree (scored 5). Responses to these 12 items were averaged items $(M=3.482, S D=0.408)$. Cronbach's alpha for this scale was 0.821 .

\section{Teacher's experience}

Teacher's experience is measured by the number of years that a teacher has been teaching $(M=$ 15.99; SD = 11.360; see Table 1).

\section{Gender}

In our sample, $62.5 \%$ of the teachers were females and $37.5 \%$ were males; this reflects exactly the gender composition of teachers in Flemish secondary education. 
Table 1. Descriptive statistics: frequency at teacher level ( $N$ teacher) and school level ( $N$ school) minimum score (Min), maximum score (Max), mean (for interval variables) and percentage (for categorical variables), standard deviation (SD) and Cronbach's alpha.

\begin{tabular}{|c|c|c|c|c|c|c|c|}
\hline & $N$ school & $N$ teacher & Min & Max & Mean & SD & Alpha \\
\hline \multicolumn{8}{|l|}{ Teacher level } \\
\hline Monolingual beliefs & & 603 & 1 & 5 & 3.740 & 0.624 & 0.816 \\
\hline Trust in students & & 607 & 1 & 4.9 & 3.191 & 0.499 & 0.827 \\
\hline Sense of self-efficacy & & 621 & 2.42 & 5 & 3.482 & 0.408 & 0.821 \\
\hline Experience & & 670 & 0 & 55 & 15.99 & 11.36 & \\
\hline Gender & & 674 & & & & & \\
\hline Female & & 421 & 0 & 1 & $62.5 \%$ & & \\
\hline Male (ref.) & & 253 & 0 & 1 & $37.5 \%$ & & \\
\hline Track & & 558 & & & & & \\
\hline Technical & & 108 & 0 & 1 & $19.4 \%$ & & \\
\hline Vocational & & 207 & 0 & 1 & $37.1 \%$ & & \\
\hline Other & & 105 & 0 & 1 & $37.1 \%$ & & \\
\hline Academic (ref) & & 138 & 0 & 1 & $18.8 \%$ & & \\
\hline \multicolumn{8}{|l|}{ School level } \\
\hline Ethnic minority composition & 48 & 86 & & & & & \\
\hline $0-20 \%$ & 13 & 172 & 0 & 1 & $27.1 \%$ & & \\
\hline $21-40 \%$ & 7 & 100 & 0 & 1 & $14.6 \%$ & & \\
\hline $41-60 \%$ & 9 & 129 & 0 & 1 & $18.8 \%$ & & \\
\hline $61-80 \%$ & 13 & 187 & 0 & 1 & $27.1 \%$ & & \\
\hline $81-100 \%$ (ref.) & 6 & 86 & 0 & 1 & $12.5 \%$ & & \\
\hline School sector & 48 & 674 & & & & & \\
\hline Private/Catholic & 24 & 433 & 0 & 1 & $50.0 \%$ & & \\
\hline Public (ref.) & 24 & 241 & 0 & 1 & $50.0 \%$ & & \\
\hline
\end{tabular}

\section{Curriculum track}

We distinguish between four types of teacher according to the tracking system in which they function (see Table 1). In secondary education in Flanders, most students are tracked into three different tracks: the academic, technical and vocational track. The academic track (ASO) prepares students for higher education, the technical track (TSO) offers technical training and the vocational track (BSO) focuses on specific vocations. Most teachers only teach in one of these tracks. Teachers who are assigned to more than one track and other types of teachers (e.g. teachers assigned to L2 submersion classes for newcomers) are categorized as 'Others' (see Table 1).

\section{Ethnic minority composition}

School ethnic minority composition is measured by the percentage of ethnic minority students (in the survey: 'allochtonen') in a school, as estimated by the teachers. We distinguished five categories of school ethnic minority composition: (1) $0-20 \%$, (2) $21-40 \%$, (3) $41-60 \%$, (4) $61-80 \%$ and (5) $81-$ $100 \%$.

Table 2. Items of monolingual beliefs in education scale.

\begin{tabular}{|c|c|c|}
\hline Item & Description & $\begin{array}{l}\text { (Completely) } \\
\text { Agree }\end{array}$ \\
\hline 1 & Non-Dutch speaking pupils should not be allowed to speak their home language at school & $77.3 \%$ \\
\hline 2 & $\begin{array}{l}\text { The most important cause of academic failure of non-Dutch speaking pupils is their insufficient } \\
\text { proficiency in Dutch }\end{array}$ & $78.2 \%$ \\
\hline 3 & $\begin{array}{l}\text { The school library (classroom library, media library) should also include books in the different home } \\
\text { languages of the pupils }\end{array}$ & $12.8 \%$ \\
\hline 4 & Non-Dutch speaking pupils should be offered the opportunity to learn their home language at school & $6.8 \%$ \\
\hline 5 & By speaking their home language at school, non-Dutch speaking pupils do not learn Dutch sufficiently & $72.1 \%$ \\
\hline 6 & Non-Dutch speaking pupils should be offered regular subjects in their home language & $3.2 \%$ \\
\hline 7 & $\begin{array}{l}\text { It is more important that non-Dutch speaking pupils obtain a high level of proficiency in Dutch than in } \\
\text { their home language }\end{array}$ & $44.7 \%$ \\
\hline 8 & It is in the interest of the pupils when they are punished for speaking their home language at school & $29.1 \%$ \\
\hline
\end{tabular}

Note: Percentage of teachers answering 'agree' and 'completely agree' are shown ( $N$ teachers $=674 ; N$ schools $=48$ ). 


\section{School sector}

The school sector variable was split between 24 publicly run schools and 24 privately run (Catholic) schools. This more or less reflects the educational situation in Flanders where around half of the schools are private (Catholic) schools.

\section{Results}

\section{Research question 1}

To which extent do teachers in secondary education adhere to the monolingual language policies as presently implemented in the Flemish education system? To answer this question, we examined teachers' responses to the items of the 'monolingualism scale'. The percentages of teachers that responded 'agree' or 'completely agree' are shown in Table 2. These figures indicate that the vast majority of teachers participating in the study support the current monolingual policies in Flemish education. $\mathbf{7 7 . 3 \%}$ of the teachers agree that students should not be allowed to speak a foreign language at school (item 1) and $78.2 \%$ of the teachers state that linguistic deficiency is the most important cause of poor educational performance of non-native speakers (item 2). In addition, only a small minority (about 5\%) of teachers is in favor of mother tongue education or bilingual education (see items 4 and 6). It is also noteworthy that almost a third of the teachers in our sample believe that students should be punished for speaking their mother tongue for their own benefit (see item 8).

To what degree do teachers' monolingualism beliefs vary between schools? To answer this question, we calculated the variance components from the unconditional model. We are particularly interested in the variance at school level, which is computed as the between-school variance component divided by the sum of the within-school variance and between-school variance $\left[\mathrm{\tau} 0 /\left(\sigma^{2}+\tau 0\right)\right]$. We calculated that teachers' monolingual beliefs varied significantly across schools $(18.84 \% ; p<.001)$.

\section{Research question 2}

Above, we demonstrated that teachers strongly support monolingual policies in education, while there is a significant variation between schools. Now we want to further explore these monolingual beliefs by answering the second research question: what are the effects of school ethnic composition and curriculum track on teachers' beliefs about monolingualism.

In Table 3, we present the results of the multilevel regression analysis on teachers' monolingual beliefs. At teacher level, gender is the only variable that has a significant effect: female teachers expressed less support for monolingual policies in education than their male colleagues $(b=$ $-0.109 ; p=.029$; standardized effect $\left.\left[b^{*}\right]=-0.084\right)$. At the school level, the schools' ethnic composition is related to individual teachers' monolingual beliefs and this relationship is curvilinear: the level of monolingual beliefs peaks in schools with a balanced ethnic composition, that is, in schools with a 40-60\% ethnic minority students $(M=3.908)$, whereas teachers express less monolingual beliefs in schools with almost no ethnic minority students $(0-20 \% ; M=3.616)$, and monolingual beliefs are the lowest in schools with almost exclusively ethnic minority students $(80-100 \%: M=$ 3.527). The curvilinear relationship between school ethnic composition and monolingual beliefs is illustrated by Figure 1.

However, there is no significant relation between curriculum track and teachers' monolingual beliefs.

\section{Research question 3}

In the above section, we examined the determinants of monolingual beliefs of teachers; in this section, we focus on the effects of these beliefs on teachers' trust in their pupils and estimation of their self-efficacy. The results shown in Figure 2 and Table 4 indicate that stronger monolingual 
Table 3. Multilevel regression: determinants of teachers' monolingual beliefs ( $N$ teachers $=674 ; N$ schools $=48$ ).

\begin{tabular}{|c|c|c|c|}
\hline & $B$ & SE & $p$ \\
\hline Intercept & 3.527 & 0.134 & $* * * *$ \\
\hline \multicolumn{4}{|l|}{ Gender } \\
\hline Female & -0.109 & 0.050 & * \\
\hline \multicolumn{4}{|l|}{ Ref: male } \\
\hline Experience & 0.002 & 0.002 & \\
\hline \multicolumn{4}{|l|}{ Track } \\
\hline Technical & 0.096 & 0.078 & \\
\hline Vocational & 0.125 & 0.073 & \\
\hline Other & -0.010 & 0.095 & \\
\hline \multicolumn{4}{|c|}{ Ref: academic } \\
\hline \multicolumn{4}{|c|}{ Ethnic minority composition, \% } \\
\hline $0-20$ & 0.089 & 0.125 & \\
\hline $21-40$ & 0.120 & 0.139 & \\
\hline $41-60$ & 0.381 & 0.126 & $* *$ \\
\hline $61-80$ & 0.224 & 0.120 & $\circ$ \\
\hline \multicolumn{4}{|l|}{ Ref: 81-100 } \\
\hline \multicolumn{4}{|l|}{ School sector } \\
\hline Private/Catholic & 0.023 & 0.071 & \\
\hline Ref: public & & & \\
\hline
\end{tabular}

beliefs are related to lower levels of trust in the academic engagement of their pupils $(b=-0.203 ; p$ $\left.<.001 ; b^{*}=-0.253\right)$. However, no relation was found between monolingual beliefs and sense of selfefficacy $(b=0.011 ; p=.701)$.

Although other effects did not constitute the focus of this third research question, it is worth noting that teachers' trust in students decreases as the share of ethnic minority students in a school increases, and teachers have more trust in students when teaching in the academic track than in technical, vocational or other tracks. The only significant effect on self-efficacy is school sector.

\section{Discussion}

In order to deepen our understanding at micro-meso-macro level of the dynamic interaction between language policies, beliefs and practices in education, three objectives were outlined in

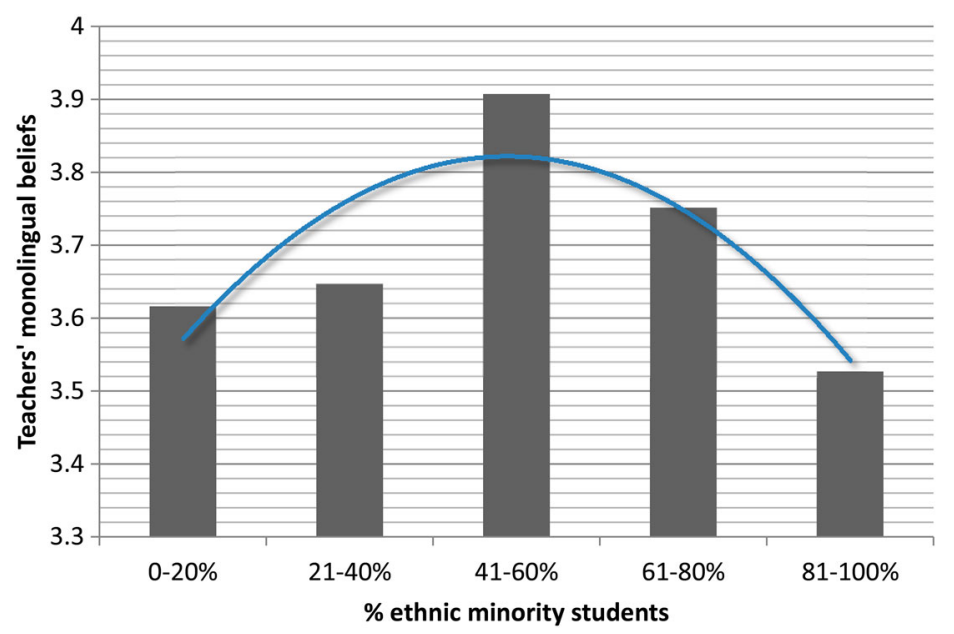

Figure 1. An illustration of the curvilinear relationship between school ethnic composition (as estimated by teachers) and monolingual beliefs ( $N$ teachers $=674 ; N$ schools $=48$ ). 


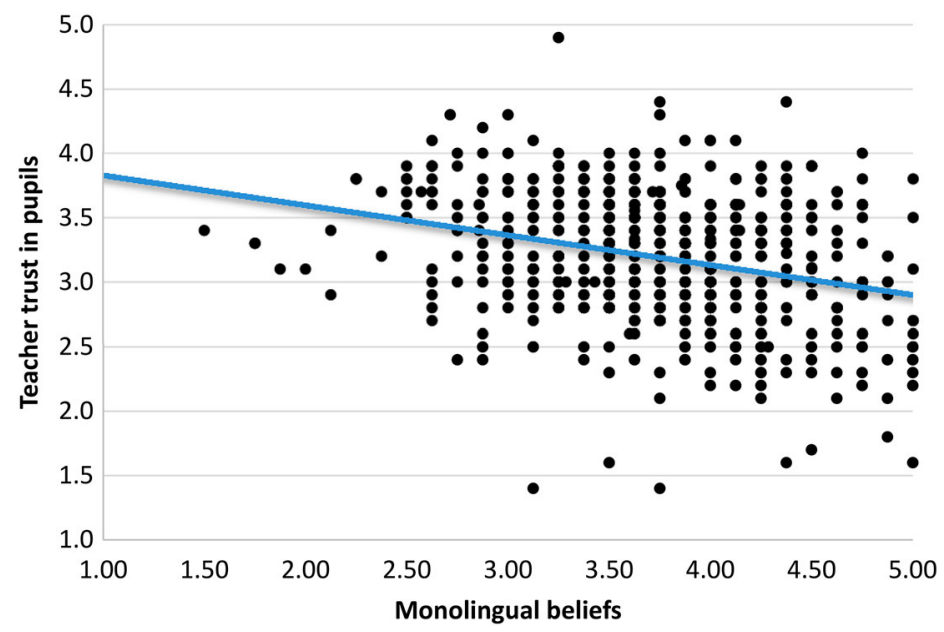

Figure 2. Relation between teachers' monolingual perceptions and the level of trust teachers have in their pupils ( $N$ teachers $=674$; $N$ schools $=48$ ).

the present study. The first objective was to explore the degree of teachers' monolingual beliefs and the variation of these beliefs between schools. Secondly, we wanted to examine if school characteristics determine the level of teachers' adherence to or rejection of monolingual education ideologies. And thirdly, we wanted to gain insight into the relationship between teachers' monolingual beliefs on the one hand and teacher expectations on the other hand.

Our findings indicate that the beliefs of teachers regarding the use of (home) language in education coincide to a large extent with the monolingual policies implemented in Flemish education. In addition, there was an association between the monolingual beliefs of teachers and the level of

Table 4. Multilevel regression: the impact of monolingual perceptions on teachers' trust in students and sense of self-efficacy ( $N$ teachers $=674 ; N$ schools $=48$ ).

\begin{tabular}{|c|c|c|c|c|c|c|}
\hline & \multicolumn{3}{|c|}{ Trust } & \multicolumn{3}{|c|}{ Self-efficacy } \\
\hline & $B$ & SE & $p$ & $B$ & SE & $p$ \\
\hline Intercept & 3.909 & 0.148 & *** & 3.511 & 0.127 & \\
\hline Monolingualism & -0.203 & 0.030 & $* * *$ & 0.011 & 0.028 & \\
\hline \multicolumn{7}{|l|}{ Gender } \\
\hline Female & 0.022 & 0.036 & & 0.023 & 0.034 & \\
\hline \multicolumn{7}{|l|}{ Ref: Male } \\
\hline $\begin{array}{l}\text { Experience } \\
\text { Track }\end{array}$ & \multicolumn{5}{|c|}{ Track } & \\
\hline Technical & -0.125 & 0.060 & * & 0.053 & 0.058 & \\
\hline Vocational & -0.228 & 0.061 & *** & 0.005 & 0.062 & \\
\hline Other & -0.115 & 0.057 & * & 0.102 & 0.057 & \\
\hline \multicolumn{7}{|c|}{ Ref: academic } \\
\hline \multicolumn{7}{|c|}{ Ethnic minority composition, $\%$} \\
\hline $0-20$ & 0.372 & 0.107 & $* * *$ & -0.026 & 0.059 & \\
\hline $21-40$ & 0.367 & 0.118 & $* *$ & 0.019 & 0.066 & \\
\hline $41-60$ & 0.179 & 0.108 & & -0.036 & 0.063 & \\
\hline $61-80$ & 0.140 & 0.102 & & -0.069 & 0.056 & \\
\hline \multicolumn{7}{|l|}{ Ref: 81-100 } \\
\hline \multicolumn{7}{|l|}{ School sector } \\
\hline $\begin{array}{l}\text { Private/Catholic } \\
\text { Ref: public }\end{array}$ & -0.013 & 0.061 & & -0.102 & 0.036 & ** \\
\hline
\end{tabular}

${ }^{*} p<.05$.

${ }^{* *} p<.01$.

${ }^{* * *} p<.001$. 
trust they have in their pupils: the stronger the monolingual beliefs are, the less trust teachers have in their pupils. From the literature, as discussed in the paragraph regarding the relation between teachers' monolingual beliefs and teacher-pupil interaction, we know that trust in pupils is related to the expectations teachers hold regarding the academic achievement of pupils. These teachers' expectations, in turn, determine the actual academic outcomes of pupils.

Contrary to our expectations, no relation was found between strong monolingual beliefs of teachers and a reduced sense of self-efficacy. Although teachers indicate that they are unable to reach the prescribed academic objectives when teaching classes with a majority of ethnic minority pupils, our findings demonstrate that teachers do not relate this to their own teaching abilities. As mentioned above, the monolingual policy framework includes the idea that insufficient Dutch language proficiency at the start of an education trajectory is a deficit that needs to be alleviated in order to achieve academic success. Therefore, insufficient language proficiency is perceived as a deficit situated at the level of pupils (and their parents) and hence is seen as something needing to be solved at that level. The teachers and teaching competencies or pedagogical and didactical approaches at teacher and school level are not questioned - in spite of rapidly changing school composition and increasing linguistic diversity.

An important relationship was found between the monolingual beliefs of teachers and the ethnic composition of a school (as estimated by the teachers). The monolingual language policies receive the most support in schools with a more or less even distribution of ethnic minority and non-minority pupils. This finding can be construed in two different ways. A first explanation is based on the 'Group Threat Theory' (Longshore 1982; Goldsmith 2004). This theory refers to situations where different ethnic groups of comparable size are present and a dominant group is (not yet) established. It is in such situations that the most intense feelings of threat are experienced and the struggle for dominance is still ongoing. In line with the Group Threat Theory, we can say that the use of the Dutch language is mostly perceived as threatened in the so-called 'mixed school' (about 50\% of ethnic minority pupils). In schools with a (numerical) majority of non-migrant pupils (so-called 'white concentration schools'), the use of the Dutch language is not threatened at all and in schools with a (numerical) majority of ethnic minority children (so-called 'black concentration schools'), the struggle for dominance has been concluded to the detriment of the Dutch language. A second, more intuitive explanation refers to the evolution the so-called 'black concentration schools' have experienced over the past few decades whereby they started out as white concentration schools, then becoming a mixed school and ending up as 'black concentration schools'. It is probable that during this evolution, these schools have gained experience and expertise in dealing with a changing school composition and addressing increasing (linguistic) diversity at school and classroom levels. Therefore, it is likely that they do not feel the need to implement a strict monolingual school policy. However, findings based on qualitative research comprising of in-depth interviews and group discussions with teachers in secondary education in Flanders (Pulinx and Van Avermaet 2015; Pulinx, Agirdag, and Van Avermaet 2014) seem to attribute the explanation of the findings to something closer to the Group Threat Theory rather than to an evolution of expertise.

These findings have clear implications for policymakers. Current education policy in Flanders, aimed at improving the achievement rate of non-Dutch speaking pupils, is based on the belief that Dutch language proficiency is a condition for academic success. However, the underlying objective - increasing language proficiency (in Dutch) by imposing the exclusive use of Dutch and the banning of other home languages in the school context - appears to be jeopardized by the interaction between teachers' language beliefs, teachers' trust in pupils and teachers' expectations about academic achievement. These beliefs are shaped by an ongoing dynamic and reciprocal interaction process between education policies and specific school contexts. Therefore, teachers can be key actors in bringing about more open and inclusive language policies in education. A transition from a monolingual toward a multilingual approach regarding home languages in education will be most successful when initiated by teachers at school and classroom level (bottom up). The opposite shift (top down) - changing regional and national language policies first - would likely be more 
difficult to initiate taking into account the strong adherence to monolingual language policies in the socio-political reality of Flanders. Earlier research programs have shown that practice-orientated and experimental approaches can lead to changes in the beliefs of teachers regarding the (linguistic) competences and academic involvement of their pupils (Valdiviezo 2009; Ramaut et al. 2013).

By supporting grassroots initiatives (small-scale projects merging bottom-up schemes based on school and classroom experiences), conducting action research and experimental research programs and professionalization of teacher training, it is possible to bring about change in school policies and teachers' beliefs (Fullan 2007; Sierens and Van Avermaet 2014). Subsequently, education and language policies at regional and national levels can be influenced by the altered beliefs and experience at school and teacher level. In other words, monolingual school policies can be contested and reconstructed at school and classroom level.

\section{Disclosure statement}

No potential conflict of interest was reported by the authors.

\section{Notes}

1. http://www.ond.vlaanderen.be/onthaalonderwijs/inhoud/historiek/ (accessed February 26, 2015).

2. http://www.senate.be/doc/const_nl.html (accessed February 26, 2015).

3. PISA: Programme for International Student Assessment (OECD), TIMSS: Trends in International Mathematics and Science Study (IEA), PIRLS: Progress in International Reading Literacy Study (IEA).

\section{ORCID}

Orhan Agirdag (1) http://orcid.org/0000-0002-5508-1501

\section{References}

Agirdag, O. 2010. "Exploring Bilingualism in a Monolingual School System: Insights from Turkish and Native Students from Belgian schools." British Journal of Sociology of Education 31 (3): 307-321.

Agirdag, O. 2014. "The Long-Term Effects of Bilingualism on Children of Immigration: Student Bilingualism and Future Earnings." International Journal of Bilingual Education and Bilingualism 17 (4): 449-464.

Agirdag, O., P. Van Avermaet, and M. Van Houtte. 2013. "School Segregation and Math Achievement: A Mixed-Method Study on the role of Self-fulfilling Prophecies." Teachers College Record 115 (3): 1-50.

Agirdag, O., and M. Van Houtte. 2011. "A Tale of Two Cities: Bridging Families and Schools." Educational Leadership 68 (8): 42-46.

Agirdag, O., M. Van Houtte, and P. Van Avermaet. 2012. "Why Does Ethnic and Socio-Economic Composition of Schools Influence Math Achievement? The Role of Sense of Futility and Futility Culture." European Sociological Review 28 (3): 366-378.

Blackledge, A., and A. Pavlenko. 2001. "Language Ideologies in Multilingual Contexts." Multilingua 20 (3): 121-140.

Blommaert, J., and P. Van Avermaet. 2008. Taal, Onderwijs en de samenleving. De kloof tussen beleid en realiteit. Berchem: EPO.

Blommaert, J., and J. Verschueren. 1998. "The Role of Language in European Nationalist Ideologies." In Language Ideologies: Practice and Theory, edited by B. Schieffelin, K. Woolard, and P. Kroskrity, 189-210. New York: Oxford University Press.

Bourdieu, P. 1979. La distinction. Critique social du jugement. Paris: Les éditions de minuit.

Bourdieu, P. 1991. Language and Symbolic Power. Cambridge: Policy Press.

Bowie, R. L., and C. L. Bond. 1994. "Influencing Teachers' Attitudes toward Black English: Are We Making a Difference?" Journal of Teacher Education 45: 112-118.

Clycq, N., C. Timmerman, P. Van Avermaet, J. Wets, and P. Hermans, eds. 2014. Oprit 14. Naar een schooltraject zonder snelheidsbeperkingen. Gent: Academia Press.

Creese, A. 2010. "Two-Teacher Classrooms, Personalized Learning and the Inclusion Paradigm in the United Kingdom." In Negotiating Language Policies in Schools. Educators as Policymakers, edited by K. Menken and 0. Garcia, 32-51. New York: Routledge. 
Crowl, T., and W. MacGinitie. 1974. "The Influence of Students' Speech Characteristics on Teachers' Evaluations of Oral Answers." Journal of Educational Psychology 66 (3): 304-308.

Cummins, J. 2011. Putting the Evidence Back into Evidence-based Policies for Underachieving Students. Strasbourg: Council of Europe.

Cummins, J. 2013. "Language and Identity in Multilingual Schools: Constructing Evidence-based Instructional Policies." In Managing Diversity in Education. Languages, Policies, Pedagogies, edited by D. Little, C. Leung, and P. Van Avermaet, 326. Bristol: Multilingual Matters.

De Meyer, I. 2008. Science Competences for the Future in Flanders. The first results from PISA 2006. Flemish Ministry of Education and Training and University of Ghent, Department of Education.

De Meyer, I., J. Pauly, and L. Van de Poele. 2005. Learning for Tomorrow's Problems in Flanders. First results from PISA 2003. Department of Education, University of Ghent.

De Rycke, L., and M. Swyngedouw. 1999. "The Value of Concentration Schools as Appreciated by Moroccan, Turks and Unskilled Belgians in Brussels." International Journal of Educational Research 31 (4): 267-281.

Dumay, X., and V. Dupriez. 2008. "Does School Composition Effect Matter? Evidence from Belgian Data." British Journal of Educational Studies 56 (4): 440-477.

Duquet, N., I. Glorieux, I. Laurijssen, and Y. Van Doorselaer. 2006. Wit krijt schrijft beter. Schooloopbanen van allochtone jongeren in beeld. Antwerpen: Garant.

Ennis, C. 1994. "Urban Secondary Teachers' Value Orientations: Social Goals for Teaching." Teaching and Teacher Education 10 (1): 109-120.

Extra, G., M. Spotti, and P. Van Avermaet. 2009. "Testing Regimes for Newcomers." In Language Testing, Migration and Citizenship. Cross-National Perspectives, edited by G. Extra, M. Spotti, and Van Avermaet, 3-33. London: Continuum.

Extra, G., and K. Yagmur, eds. 2004. Urban Multilingualism in Europe: Immigrant Minority Languages at Home and School. Clevedon: Multilingual Matters.

Flemish Parliament. 2007. Minutes Plenary Meeting. March 14.

Fullan, M. 2007. The New Meaning of Educational Change. New York: Routledge.

Garcia, O., and L. Wei. 2013. Translanguaging. Language, Bilingualism and Education. New York: Palgrave MacMillan.

Gkaintartzi, A., A. Kiliari, and R. Tsokalidou. 2015 “'Invisible' Bilingualism - 'Invisible' Language Ideologies: Greek Teachers' Attitudes Towards Immigrant Pupils' Heritage Languages." International Journal of Bilingual Education and Bilingualism 18 (1): 60-72.

Godley, A., J. Sweetland, R. Wheeler, A. Minnici, and B. Carpenter. 2006. "Preparing Teachers for Dialectally Diverse Classrooms." Educational Researcher 35 (8): 30-37.

Goldsmith, P. 2004. "School's Role in Shaping Race Relations: Evidence on Friendliness and Conflict." Social Problems 51: 587-612.

Hirtt, N., I. Nicaise, and D. de Zutter. 2007. De School van Ongelijkheid. Antwerpen: Epo.

Hoy, W., and M. Tschannen-Moran. 1999. "The Five Faces of Trust: An Empirical Confirmation in Urban Elementary Schools." Journal of School Leadership 9: 184-208.

Hu, L., and P. Bentler. 1999. "Cutoff Criteria for Fit Indexes in Covariance Structure Analysis: Conventional Criteria Versus New Alternatives." Structural Equation Modeling 6: 1-55.

Jacobs, D. 2009. De sociale lift blijft steken. De prestaties van allochtone leerlingen in de Vlaamse Gemeenschap en de Franse Gemeenschap. Brussel: Koning Boudewijnstichting.

Kroskrity, P. V., ed. 2000. Regimes of Language: Ideologies, Policies and Identities. Santa Fé, NM: School of American Research Press.

Lee, V. 2000. "Using Hierarchical Linear Modeling to Study Social Contexts: The Case of School Effects." Educational Psychologist 35 (2): 125-141.

Longshore, D. 1982. "Race Composition and White Hostility. A Research Note on the Problem of Control in Desegregated Schools." Social Forces 61: 73-78.

Mahieu, P., and N. Clycq. 2007. "School Leadership and Equity: The Case of Antwerp: A Report on Good Practices in Three Primary Schools." School Leadership \& Management 27 (1): 35-49.

Merry, M. S. 2012. "Segregation and Civic Virtue." Educational Theory 62 (4): 465-486.

Nouwen, W., and A. Vandenbroucke. 2011. "Oorzaken van segregatie in het basisonderwijs: een perceptiegestuurde marktwerking met ongelijke machts-posities van ouders en scholen." In Segregatie in het Basisonderwijs. Geen Zwart-Wit verhaal, edited by O. Agirdag, et al., 30-67. Antwerpen: Garant.

Oakes, J. 1985. Keeping Track: How Schools Structure Inequality. New Haven, CT: Yale University Press.

Pavlenko, A. 2002. "We have Room for but one Language Here': Language and National Identity in the US at the Turn of the 20th Century." Multilingua 21: 45-78.

Pulinx, R., O. Agirdag, and P. Van Avermaet. 2014. "Taal en onderwijs. Percepties en praktijken in de klas." In Oprit 14. Naar een schooltraject zonder snelheidsbeperkingen, edited by N. Clycq, C. Timmerman, P. Avermaet, J. Wets, and P. Hermans, 97-133. Gent: Academia Press.

Pulinx, R., and P. Van Avermaet. 2014. "Policies and Perceptions. Dynamic Interactions between Language Policies in Education and Teachers' Beliefs." Revue Française de Linguistique Appliquée XIX (2): 9-27. 
Pulinx, R., and P. Van Avermaet. 2015. "Integration in Flanders (Belgium) - Citizenship as Achievement. How Intertwined are 'Citizenship' and 'Integration' in Flemish Language Policies?" Journal of Language and Politics 14 (3): $335-358$.

Ramaut, G., S. Sierens, K. Bultinck, P. Van Avermaet, S. Slembrouck, K. Van Gorp, and M. Verhelst. 2013. Evaluatieonderzoek van het project 'Thuistaal in onderwijs' (2009-2012): Eindrapport [Research project evaluating the 'Home Language in Education' project (2009-2012): Final report]. Gent: Ghent University and KU Leuven.

Rosenthal, R., and L. Jacobson. 1968. Pygmalion in the Classroom. New York: Holt, Rinehart \& Winston.

Rumberger, R., and G. Palardy. 2005. "Does Segregation Still Matter? The Impact of Student Composition on Academic Achievement in High School." The Teachers College Record 107 (9): 1999-2045.

Shohamy, E. 2006. Language Policy. Hidden Agendas and New Approaches. New York: Routledge.

Sierens, S., and P. Van Avermaet. 2014. "Language Diversity in Education: Evolving from Multilingual Education to Functional Multilingual Learning." In Managing Diversity in Education: Languages, Policies, Pedagogies, edited by D. Little, C. Leung, and P. Van Avermaet, 204-222. Bristol: Multilingual Matters.

Smet, P. 2011. "Samen taalgrenzen verleggen [Moving linguistic boundaries together]." Policy Paper Flemish Minister of Education and Training.

Spolsky, B. 2004. Language Policy. Cambridge: University Press.

Tschannen-Moran, M., and W. Hoy. 2001. "Teacher Efficacy: Capturing an Elusive Construct." Teaching and Teacher Education 17: 783-805.

Vaish, V. 2012. "Teacher Beliefs Regarding Bilingualism in an English Medium Reading Program." International Journal of Bilingual Education and Bilingualism 15 (1): 53-69.

Valdiviezo, L. 2009. "Bilingual Intercultural Education in Indigenous Schools: An Ethnography of Teacher Interpretations of Government Policy." International Journal of Bilingual Education and Bilingualism 12 (1): 61-79.

Van Avermaet, P. 2009. "Fortress Europe? Language Policy Regimes for Immigration and Citizenship." In Discourses on Language and Integration, edited by G. Hogan-Burn, C. Mar-Molinero, and P. Stevenson, 15-44. Amsterdam: John Benjamins.

Vandenbroucke, F. 2006. "De lat hoog voor talen in iedere school. Goed voor de sterken, sterk voor de zwakken [Setting the bar high for languages in every school. Good for the strong, strong for the weak]." http://www2.sip.be:40000/ groepen/nederlands/paginas/talenbeleidsnota_200702.pdf.

Vandenbroucke, F. 2007. "Taal: een sociale kwestie." Presented at the symposium 'Overeind in Babel. Talen in Europa', Brussels, Belgium, September 14.

Van Houtte, M. 2011. "So Where's the Teacher in School Effects Research? The Impact of Teachers' Beliefs, Culture, and Behavior on Equity and Excellence." In Education Equity and Excellence in Education Towards Maximal Learning Opportunities for All Students, edited by K. Van den Branden, M. Van Houtte, and P. Van Avermaet, 75-95. New York: Routledge.

Van Maele, D., and M. Van Houtte. 2011. "The Quality of School Life: Teacher-Student Trust Relationships and the Organizational School Context." Social Indicators Research 100 (1): 85-100.

Vertovec, S. 2007. "Superdiversity and Its Implications." Ethnic and Racial Studies 30 (6): 1024-1054.

Wheeler, R. S. 2008. "Becoming Adept at Code-Switching." Educational Leadership 65 (7): 54-58.

Woolard, K. 1998. "Introduction: Language Ideology as a Field of Inquiry." In Language Ideologies: Practice and Theory, edited by B. Schieffelin, K. Woolard, and P. Kroskrity. New York: Oxford University Press. 